\title{
Implantation of standardized beta-cell grafts in a liver segment of IDDM patients: graft and recipient characteristics in two cases of insulin-independence under maintenance immunosuppression for prior kidney graft
}

\author{
B. Keymeulen ${ }^{1}$, Z. Ling ${ }^{1}$, F. K. Gorus ${ }^{1}$, G. Delvaux ${ }^{1}$, L. Bouwens ${ }^{1}$, A. Grupping ${ }^{1}$, C. Hendrieckx ${ }^{1}$, \\ M. Pipeleers-Marichal ${ }^{1}$, C. Van Schravendijk ${ }^{1}$, K. Salmela ${ }^{2}$, D. G. Pipeleers ${ }^{1}$ \\ ${ }^{1}$ Diabetes Research Center, Vrije Universiteit Brussel, Brussels, Belgium \\ ${ }^{2}$ Department of Surgery, University of Helsinki, Helsinki, Finland
}

\begin{abstract}
Summary Islet allografts in insulin-dependent diabetic (IDDM) patients exhibit variable survival lengths and low rates of insulin-independence despite treatment with anti-T-cell antibodies and maintenance immunosuppression. Use of poorly characterized freshly isolated preparations makes it difficult to determine whether failures are caused by variations in donor tissue. This study assesses survival of standardized beta-cell allografts in C-peptide negative IDDM patients on maintenance immunosuppression following kidney transplantation and without receiving anti-T-cell antibodies or additional immunosuppression. Human islets were isolated from pancreatic segments after maximal $20 \mathrm{~h}$ cold-preservation. During culture, preparations were selected according to quality control tests and combined with grafts with standardized cell composition $(\geq 50 \%$ beta cells), viability ( $\geq 90 \%$ ), total beta-cell number (1 to $2 \cdot 10^{6} / \mathrm{kg}$ body weight) and insulin-producing capacity ( 2 to $4 \mathrm{nmol} \cdot$ graft $^{-1} \cdot \mathrm{h}^{-1}$ ). Grafts were injected in a liver segment through the repermeabilized umbilical vein. After 2 weeks C-peptide positivity, four out of seven recipients became C-peptide negative; two of them were initially $\mathrm{GAD}_{65}$-antibody positive and exhibited a rise in titre during graft destruc-
\end{abstract}

tion. The other three patients remained C-peptide positive for more than 1 year, two of them becoming insulin-independent with near-normal fasting glycaemia and $\mathrm{HbA}_{1}$; they remained $\mathrm{GAD}_{65^{-}}$and islet cell antibody negative. The three patients with surviving grafts presented a history of anti-thymocyte globulin therapy at kidney transplantation. Long-term surviving grafts increased C-peptide release following intravenous glucagon or oral glucose but not following intravenous glucose. Thus, cultured human beta-cells can survive for more than 1 year in IDDM patients on maintenance anti-rejection therapy for a prior kidney graft and without the need for an increased immunosuppression at the time of implantation. The use of functionally standardized beta-cell grafts helps to identify recipient and graft factors which influence their survival and metabolic effects. Insulin-independence can be achieved by injection of 1.5 million beta-cells per $\mathrm{kg}$ body weight in a liver segment. These beta-cell implants respond well to adenylcyclase activators but poorly to glucose. [Diabetologia (1998) 41: 452-459]

Keywords Diabetes mellitus, transplantation, islets, beta cells, autoantibodies.
Received: 24 October 1997 and in revised form: 29 November 1997

Abbreviations: IDDM, Insulin-dependent diabetes mellitus; IEQ, islet equivalent number; ATG, Anti-thymocyte globulins; ICA, islet cell antibody.

Corresponding author: Prof. Daniel G. Pipeleers, Diabetes Research Center, Laarbeeklaan 103, 1090-Brussels, Belgium
Islet transplantation can restore insulin production in insulin-dependent diabetic (IDDM) patients in whom this capacity had been lost for many years [1-7]. This observation has been made in kidney and liver recipients, where advantage is taken of the need for a continuous immune suppression. Survival of the grafts is variable, but generally less than 1 year. A prolonged beta-cell function with a state of insulin-independence after one year was achieved in $7 \%$ of the cases recorded by the Islet Transplant Reg- 
Table 1. Comparison of recipient and graft characteristics in transplants with different outcome

\begin{tabular}{|c|c|c|c|c|c|c|c|}
\hline \multirow[t]{2}{*}{ Graft survival } & \multicolumn{3}{|l|}{$>52$ weeks } & \multicolumn{4}{|l|}{$<3$ weeks } \\
\hline & A (female) & B (male) & $\mathrm{C}$ (male) & $\mathrm{D}$ (female) & $\mathrm{E}$ (male) & $\mathrm{F}$ (male) & G (male) \\
\hline \multicolumn{8}{|l|}{ Recipient characteristics } \\
\hline $\begin{array}{l}\text { History of diabetes } \\
\text { Age at clinical onset (years) } \\
\text { HLA DQ Genotype (relative risk) } \\
\text { IDDM in 1st degree relative }\end{array}$ & $\begin{array}{l}3 \\
5 \\
0 / 5\end{array}$ & $\begin{array}{l}7 \\
33 \\
0 / 6\end{array}$ & $\begin{array}{l}19 \\
6 \\
0 / 7\end{array}$ & $\begin{array}{l}9 \\
33 \\
3 / 8\end{array}$ & $\begin{array}{l}18 \\
2 \\
0 / 8\end{array}$ & $\begin{array}{l}11 \\
22 \\
0 / 9\end{array}$ & $\begin{array}{l}9 \\
33 \\
0 / 4\end{array}$ \\
\hline $\begin{array}{l}\text { Status at implantation } \\
\text { Age (years) } \\
\text { Body weight }(\mathrm{kg}) \\
\text { Insulin dose }\left(\mathrm{IU} \cdot \mathrm{kg}^{-1} \cdot 24 \mathrm{~h}^{-1}\right) \\
\mathrm{ICA}-\mathrm{GAD}_{65}-\mathrm{Ab}\end{array}$ & $\begin{array}{l}38 \\
59 \\
0.8 \\
\text { neg }\end{array}$ & $\begin{array}{l}38 \\
63 \\
0.9 \\
\text { neg }\end{array}$ & $\begin{array}{l}52 \\
69 \\
0.7 \\
\text { neg }\end{array}$ & $\begin{array}{l}39 \\
68 \\
0.7 \\
\text { neg }\end{array}$ & $\begin{array}{l}46 \\
73 \\
0.5 \\
\text { GAD } \oplus\end{array}$ & $\begin{array}{l}45 \\
72 \\
0.8 \\
\text { neg }\end{array}$ & $\begin{array}{l}34 \\
67 \\
0.9 \\
\text { GAD } \oplus\end{array}$ \\
\hline $\begin{array}{l}\text { Immunosuppressive treatment } \\
\text { History of ATG treatment } \\
\text { CyA blood through level }(\mathrm{ng} / \mathrm{ml}) \\
\text { Azathioprine }\left(\mathrm{mg} \cdot \mathrm{kg}^{-1} \cdot \mathrm{day}^{-1}\right) \\
\text { Methylprednisolone }\left(\mathrm{mg} \cdot \mathrm{kg}^{-1} \cdot \mathrm{day}^{-1}\right)\end{array}$ & $\begin{array}{l}\text { yes } \\
126 \\
1.7 \\
0.14\end{array}$ & $\begin{array}{l}\text { yes } \\
109 \\
1.8 \\
0.08\end{array}$ & $\begin{array}{l}\text { yes } \\
89 \\
1.5 \\
0.09\end{array}$ & $\begin{array}{l}\text { no } \\
93 \\
0.7 \\
0.09\end{array}$ & $\begin{array}{l}\text { no } \\
47 \\
1.1 \\
0.05\end{array}$ & $\begin{array}{l}\text { no } \\
103 \\
1.0 \\
0.06\end{array}$ & $\begin{array}{l}\text { no } \\
147 \\
1.9 \\
0.06\end{array}$ \\
\hline \multicolumn{8}{|l|}{ Graft characteristics } \\
\hline $\begin{array}{l}\text { Donor segments }(n) \\
\text { Donor age (years) } \\
\text { Cold ischaemia (h) }\end{array}$ & $\begin{array}{l}6 \\
26(16-41) \\
11(5-16)\end{array}$ & $\begin{array}{l}8 \\
37(16-60) \\
8(4-12)\end{array}$ & $\begin{array}{l}8 \\
22(3-57) \\
12(6-18)\end{array}$ & $\begin{array}{l}8 \\
41(19-52) \\
11(4-19)\end{array}$ & $\begin{array}{l}9 \\
40(24-60) \\
13(3-16)\end{array}$ & $\begin{array}{l}7 \\
39(12-53) \\
10(7-15)\end{array}$ & $\begin{array}{l}8 \\
40(15-50) \\
11(9-20)\end{array}$ \\
\hline $\begin{array}{l}\text { Cellular composition } \\
\% \text { beta/alpha/delta } \\
\% \text { duct cells } \\
\% \text { MHC-class II positive cells } \\
\% \text { damaged cells }\end{array}$ & $\begin{array}{l}70 / 10 / 2 \\
18 \\
<0.1 \\
2\end{array}$ & $\begin{array}{l}59 / 7 / 6 \\
26 \\
<0.1 \\
6\end{array}$ & $\begin{array}{l}51 / 12 / 5 \\
32 \\
<0.1 \\
4\end{array}$ & $\begin{array}{l}68 / 10 / 4 \\
21 \\
<0.1 \\
7\end{array}$ & $\begin{array}{l}50 / 10 / 8 \\
40 \\
<0.1 \\
3\end{array}$ & $\begin{array}{l}66 / 10 / 6 \\
13 \\
<0.1 \\
4\end{array}$ & $\begin{array}{l}51 / 10 / 7 \\
39 \\
<0.1 \\
6\end{array}$ \\
\hline $\begin{array}{l}\text { Beta cells } \\
\text { Number: } 10^{6} \text { (per kg body weight) } \\
\text { Insulin synthesis }\left(\mathrm{nmol} \cdot \text { graft }^{-1} \cdot \mathrm{h}^{-1}\right) \\
\% \text { cryopreserved }\end{array}$ & $\begin{array}{l}1.8 \\
4.4 \\
0\end{array}$ & $\begin{array}{l}1.5 \\
2.0 \\
0\end{array}$ & $\begin{array}{l}0.9 \\
3.1 \\
30\end{array}$ & $\begin{array}{l}1.5 \\
3.8 \\
27\end{array}$ & $\begin{array}{l}1.1 \\
1.8 \\
37\end{array}$ & $\begin{array}{l}1.4 \\
2.4 \\
0\end{array}$ & $\begin{array}{l}1.4 \\
2.6 \\
0\end{array}$ \\
\hline$I E Q($ per kg BW) & 4400 & 2600 & 2700 & 5300 & 2400 & 2100 & 2400 \\
\hline Culture (days) & $10(5-18)$ & $10(2-28)$ & $7(3-11)$ & $7(4-13)$ & $10(5-18)$ & $14(4-27)$ & $14(4-20)$ \\
\hline
\end{tabular}

Data are expressed as median (range)

istry [8]. It is not clear which conditions can increase the success rate while - at the same time - being applicable at an earlier stage of the disease, i.e. before serious chronic complications such as renal failure develop. Since the immune reactivity to the allogeneic implant seems the main obstacle [9], better survival might be expected if the immunogenicity of the donor tissue is reduced or if specific immunological tolerance is induced in the recipient [10]. Both strategies have led to succesful islet allotransplantations in rodents [10]. The majority of these methods made use of cultured islet tissue which - in rodents - is known to be less immunogenic than freshly isolated islet preparations $[10,11]$. So far, studies in man have mainly used freshly isolated tissue, sometimes after a period of cryopreservation [2-7]; their long-term survival in IDDM patients was only observed following induction immunosuppression with anti-T-cell globulins and continuous anti-rejection therapy [1-7]; however, $90 \%$ of implants with this treatment failed [6, 8]. We examined whether cultured beta-cell preparations can survive in IDDM patients under maintenance immune suppression for a prior kidney graft without administration of anti-T-cell globulins. Cultured islet preparations were used with the aim of reducing their immunogenicity and of standardizing their cellular composition and their insulin producing capacity.

\section{Subjects and methods}

This study is part of a European Union program on beta-cell transplantation in diabetes [12]. The protocol has been approved by the project management group (see acknowledgements), the ethical committees of university hospitals participating in recipient recruitment or/and in graft preparation and transplantation. The present paper reports on the first seven cases of intraportal transplantation of cultured and functionally standardized beta-cell grafts. In three cases, part of the donor tissue (less than $40 \%$ ) had been cryopreserved between the culture period at $37^{\circ} \mathrm{C}$ and that at room temperature (Table 1).

Recipients. The study was conducted on C-peptide negative IDDM patients on immunosuppressive therapy for a prior kidney graft ( 2 to 6 years earlier) and with stable kidney function for minimally 1 year (creatinine clearance $36-83 \mathrm{ml} / \mathrm{min}$ ). Cri- 
teria for C-peptide negativity were undetectable plasma Cpeptide levels $(<0.03 \mathrm{nmol} / \mathrm{l})$ following intravenous glucagon $(1 \mathrm{mg})$ or glucose $(0.5 \mathrm{~g} / \mathrm{kg})$, and undetectable C-peptide in $24 \mathrm{~h}$ urine. All patients had a long-standing diabetes ( $>25$ years) with chronic complications such as polyneuropathy, proliferative retinopathy, end-stage renal disease. Exclusion criteria were obesity $(\mathrm{BMI}>28)$, disturbed liver function tests, symptomatic angina pectoris or heart failure, weak general condition, acute illness, HLA antibodies. They all gave written informed consent to this study. In the pretransplant period, selected patients were examined for the presence of islet cell and $\mathrm{GAD}_{65^{-}}$antibodies and of HLA DQ risk factors $[13,14]$.

Preparation of beta-cell grafts. Human pancreatic segments were obtained from heart-beating cadaveric donors (age 3-60 years) at European hospitals affiliated with our program (see acknowledgements) or with Eurotransplant Foundation (Leiden, The Netherlands). They were cold-preserved in University of Wisconsin solution or in Histidine - Tryptophan Ketoglutarate (HTK) solution [15] for 3 to $20 \mathrm{~h}$, the time between in situ flush and start of the isolation procedure at the central facility in Brussels. After collagenase digestion and Ficoll gradient centrifugation [16], the islet-enriched interphase was harvested, washed and cultured at $37^{\circ} \mathrm{C}$ under serum-free conditions for maximally 4 weeks [17]. If the preparations could not be used for transplantation within this period, they were cryopreserved according to the method of Rajotte et al. [18]. The selected culture conditions allow preferential survival of beta-cells [17], while depleting the preparations of debris, acinar cells, leukocytes and MHC-class II positive cells (Table 1). The functional properties of individual human betacells have been determined previously, providing data on their DNA and insulin content, rate of glucose-induced insulin release and biosynthesis [17]. On the basis of these data and on the total DNA content of the preparation and its cellular composition as determined by immunocytochemistry and electron microscopy, we have calculated, for each cultured preparation, the characteristics listed in Table 1. Beta, alpha and delta cells were identified by positivity for their specific peptides $(<2 \%$ pancreatic polypeptide cells); duct cells were recognized by their positivity for cytokeratin 19 [19], MHC -class II positive cells by their positivity for HLA-DR, DP, DQ [20]. The number of beta-cells was calculated as previously described [21, 22]. Insulin synthesis at $10.0 \mathrm{mmol} / \mathrm{l}$ glucose was measured in a representative sample [17] and then extrapolated to the entire preparation. In order to obtain a functionally standardized graft, we selected those preparations with maximally $10 \%$ damaged cells and minimally $50 \%$ beta-cells with an insulin producing capacity of minimally $10 \mathrm{pmol} \cdot 10^{6}$ beta cells ${ }^{-1} \cdot \mathrm{h}^{-1}$ (i. e. mean $-2 \mathrm{SD}$ as determined in a prior study) [17].

All selected beta-cell preparations were screened for fungi, yeast and bacteria using classical microbiologic tests. For each donor, serum was re-analysed for HIV-1, HIV-2, HTLV-1, hepatitis $\mathrm{A}, \mathrm{B}$ and $\mathrm{C}$ virus and tested for islet cell antibodies (ICA). Donor tissue was excluded for positive cultures (less than $1 \%$ ), positive serum antibody-tests, positive leukocyte crossmatch and ABO blood group mismatch.

Preparations fulfilling all criteria were then combined to reach a final beta-cell number of 1.5 million per $\mathrm{kg}$ recipient body weight and an in vitro producing capacity of 1.8 to 4.4 $\mathrm{nmol} / \mathrm{h}$. They were finally incubated at room temperature for 24 to $48 \mathrm{~h}$. Before implantation, samples were taken from the combined preparation to determine the properties listed in Table 1. In order to compare the presently used graft preparations with those in other clinical trials, their islet content was counted as islet equivalent number $(\mathrm{IEQ}=$ number of islets with average diameter $150 \mu \mathrm{m}$ ) [23]. Since each graft was de- fined by the number of beta-cells and their insulin producing capacity, we use the term beta-cell graft instead of islet graft.

Technique of implantation. The umbilical ligament was repermeabilized by laparoscopy, up to the left portal vein branch. A catheter was then inserted under fluoroscopy, guided up to a segmental part of the liver and fixed; its position was confirmed by contrast injection. Twelve to twenty-four hours later the beta-cell preparation was injected through this catheter over a 10 min period, without anaesthesia. No rise in portal pressure was measured.

Pharmacologic treatment. All patients were on insulin injections (4 times daily, total dose 40-62 IU/24 h) and on triple immunosuppressive therapy since the time of kidney transplantation (Table 1). This treatment was continued throughout the study with the following adaptations during the implantation period. For methylprednisolone, one $500 \mathrm{mg}$ injection was given $3 \mathrm{~h}$ before the graft, followed - during the first 5 days - by an oral $40 \mathrm{mg}$ dose daily. During the same period, intravenous administration of cyclosporin maintained whole blood levels of 150 to $200 \mathrm{ng} / \mathrm{ml}$ (Emit Syva Cyclosporin monoclonal assay; Behring, Marburg, Germany), and short-acting i. v. insulin kept blood glucose levels between 4.4 and $10.0 \mathrm{mmol} / \mathrm{l}$.

Patient follow-up. Patients were specifically monitored for liver, kidney and bone marrow functions. The survival of their beta-cell grafts was assessed by C-peptide assay in plasma and $24 \mathrm{~h}$ urine collections; C-peptide was measured in a radioimmunoassay using guinea pig anti-human C-peptide and ${ }^{125} \mathrm{I}$-human C-peptide (both from Linco Research Inc., St. Louis, Mo., USA) and a human C-peptide standard (Novo-Nordisk, Gentofte, Denmark). The metabolic effect of the beta-cells was monitored through blood glucose (4 times daily) and $\mathrm{HbA}_{1 \mathrm{c}}$ concentrations [24]. Islet cell antibodies and $\mathrm{GAD}_{65}$-antibodies were determined $[13,14]$.

\section{Results}

Duration of C-peptide positivity. All C-peptide negative recipients became C-peptide positive for at least 2 weeks following transplantation (Fig.1). Fasting plasma levels varied between 0.07 and $0.76 \mathrm{nmol} / \mathrm{l}$, paralleling the prevailing glycaemia $(2.2$ to $8.3 \mathrm{mmol} / \mathrm{l}$ ). Plasma glucose levels above $5.0 \mathrm{mmol} / \mathrm{l}$ were associated with C-peptide levels above 0.20 $\mathrm{nmol} / \mathrm{l}$. The $24 \mathrm{~h}$ urine collections contained 0.3 to 7.6 nmol C-peptide. During the third post-transplantation week, four of the recipients became C-peptide negative, their fasting plasma levels falling under $0.03 \mathrm{nmol} / \mathrm{l}$ (Fig. 1) and the $24 \mathrm{~h}$ urine levels under 0.3 nmol. Return to C-peptide negativity was preceded by a dissociation between plasma C-peptide and glucose levels. In the three other recipients, C-peptide positivity remained for longer than 1 year, with plasma and $24 \mathrm{~h}$ urine levels which were the same (patient C) or higher (patients A and B) than during the first 2 weeks (Fig. 1).

Metabolic control. In the four recipients who returned to C-peptide negativity, daily insulin doses were comparable to those at pretransplantation (Fig.1). Fast- 


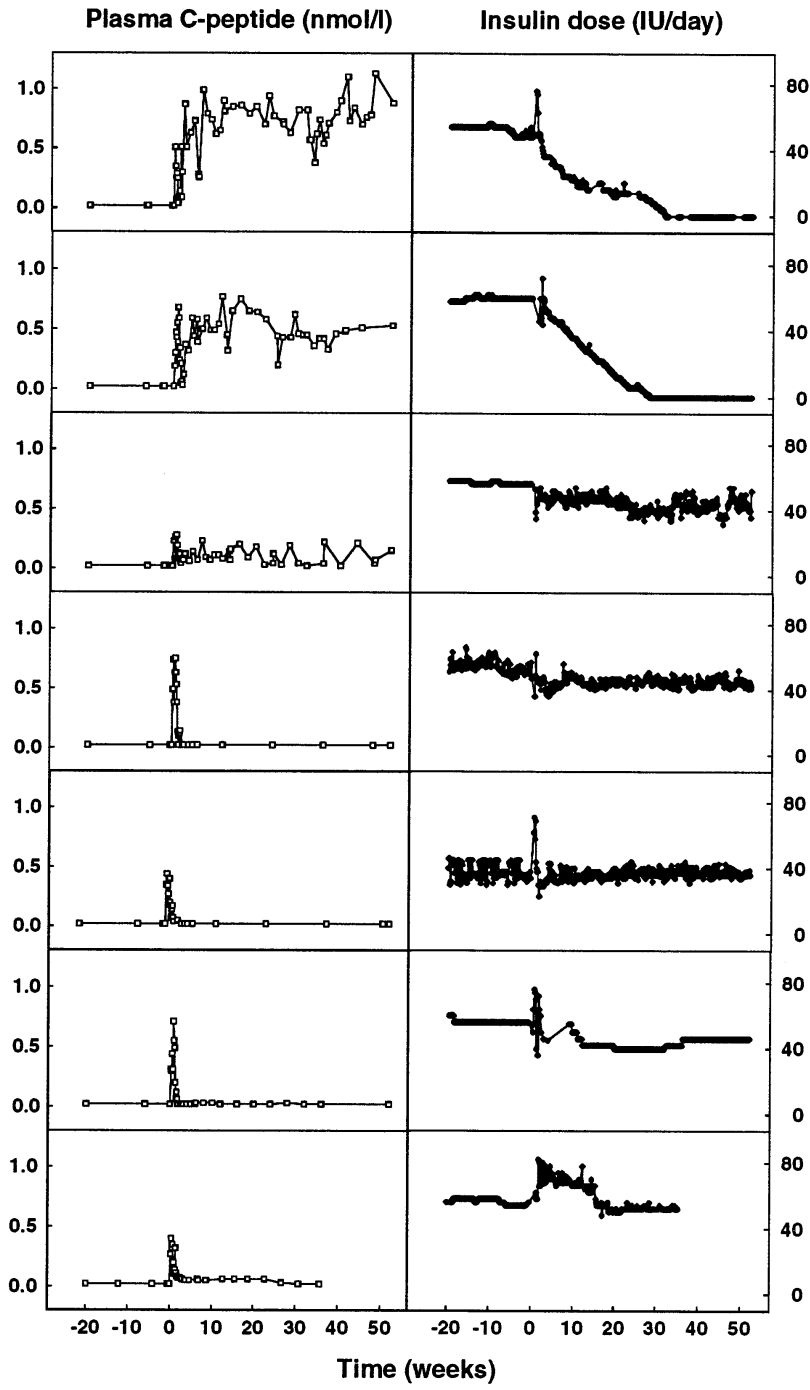

Fig. 1. Fasting plasma C-peptide, daily insulin dose, fasting capillary glycaemia, and $\mathrm{HbA}_{1 \mathrm{c}}$ levels (dotted line is upper normal), from pretransplantation week 20 to post-transplantation week 52 in the seven IDDM patients receiving a beta-cell graft in a liver segment

ing plasma glucose varied from hypo- to hyperglycaemic values and $\mathrm{HbA}_{1 \mathrm{c}}$ levels exceeded the upper normal level (Fig. 1). In the C-peptide positive recipient (patient C) with low C-peptide, daily insulin dose was $20 \%$ lower than at pretransplantation, severe fasting hypo- or hyperglycaemia became rare and $\mathrm{HbA}_{1 \mathrm{c}}$ levels decreased to upper normal (Fig. 1). In the two other C-peptide positive recipients (patients $\mathrm{A}$ and $\mathrm{B}$ ), daily insulin doses were progressively decreased to zero over 7 months; these patients have exhibited normal and stable fasting glycaemia and nearnormal $\mathrm{HbA}_{1 \mathrm{c}}$ levels for more than 1 year (Fig. 1).

Secretory responsiveness of established beta-cell grafts. The three C-peptide positive recipients were

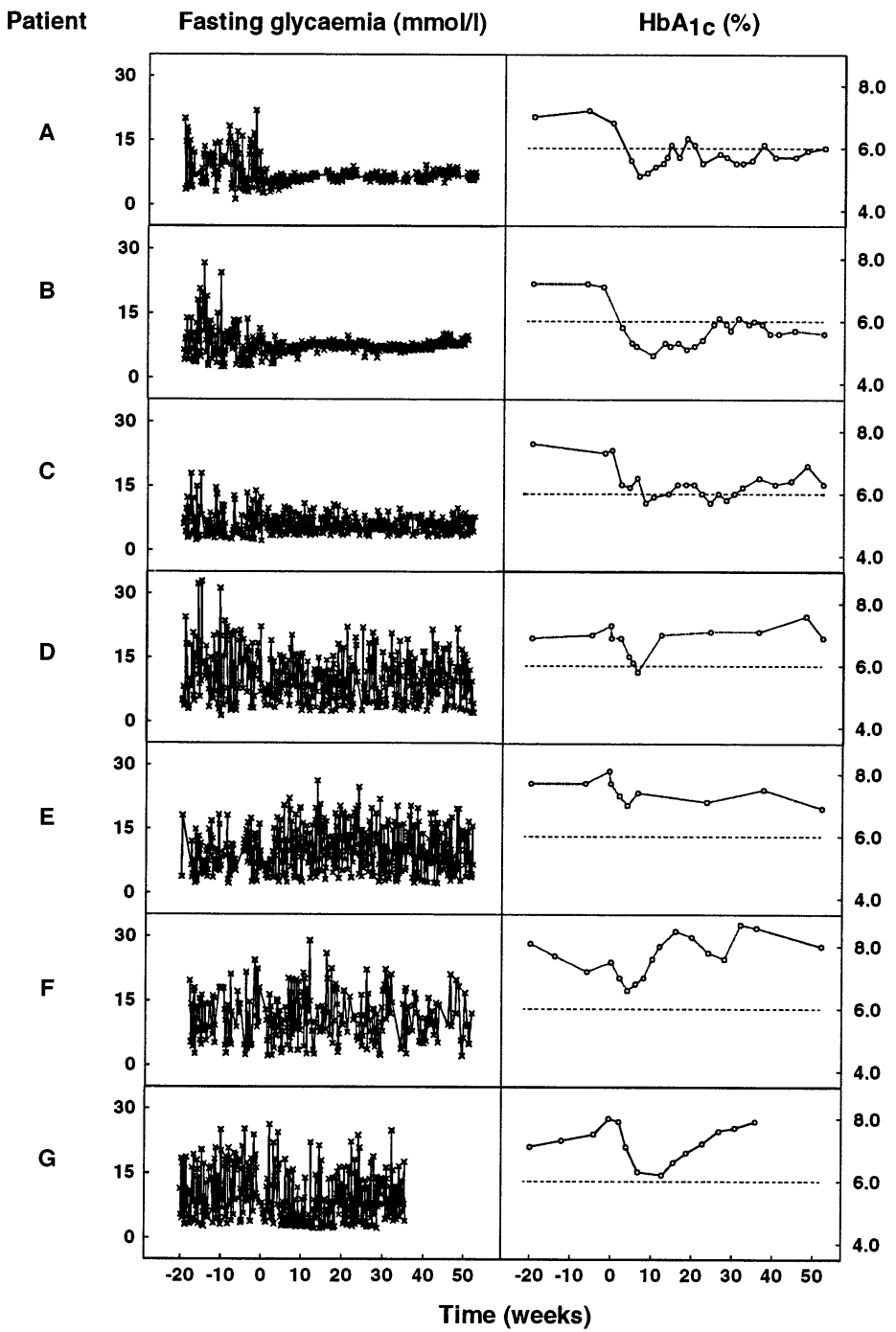

repeatedly submitted to stimulation tests of their implanted beta-cells. In all three, and at all tested time points (months 1, 3, 6, 9 and 12) intravenous glucagon increased plasma C-peptide after 5 to $20 \mathrm{~min}$, with a 2 to 2.5 -fold rise at min 10 . Figure 2 shows values measured in the two insulin-independent patients at post-transplantation month 12 . Responses to intravenous glucose were minor (maximally $30 \%$ ) both in a state of insulin-dependence and -independence (Fig.2). Oral glucose tolerance tests were only carried out in the two insulin-independent patients. Despite its minor rise in glycaemia - as compared to the intravenous test -, the oral test resulted in a 2 to 3fold increase in C-peptide between $\min 30$ and 180 (Fig. 2).

Side-effects. In none of the recipients did the graft injection into a liver segment lead to any perturbation in liver function tests (aspartate and alanine aminotransferase, alkaline phosphatase, gamma-glutamyl transpeptidase, bilirubin, prothrombin time). During 1 year follow-up none of the recipients developed a rejection episode for the kidney or became cy- 


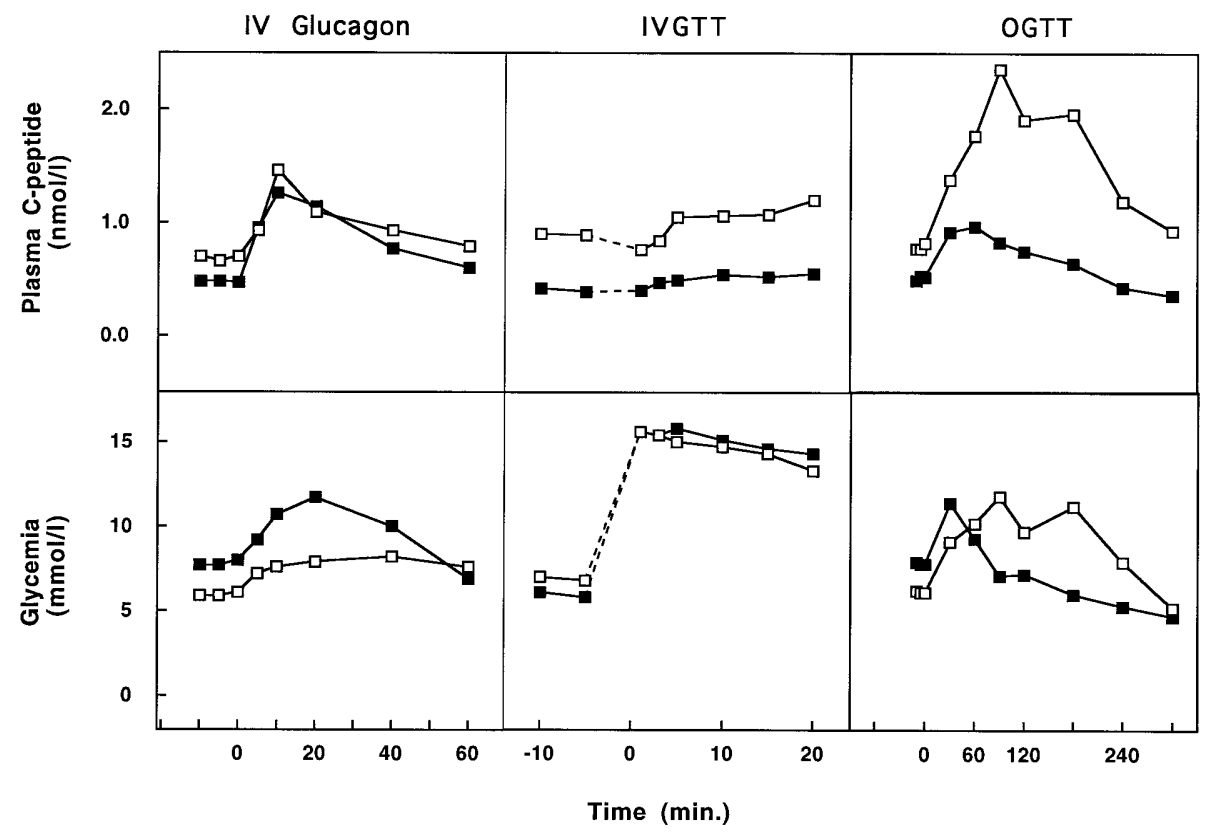

Fig. 2. Plasma C-peptide and glucose after intravenous glucagon $(1 \mathrm{mg})$, intravenous glucose $(0.5 \mathrm{~g} / \mathrm{kg})$, oral glucose $(75 \mathrm{~g})$ in the two insulin-independent patients (A $\square, \mathrm{B} \square)$ at posttransplantation week 52. Representation of IVGT data as published for the ICARUS protocol [25]

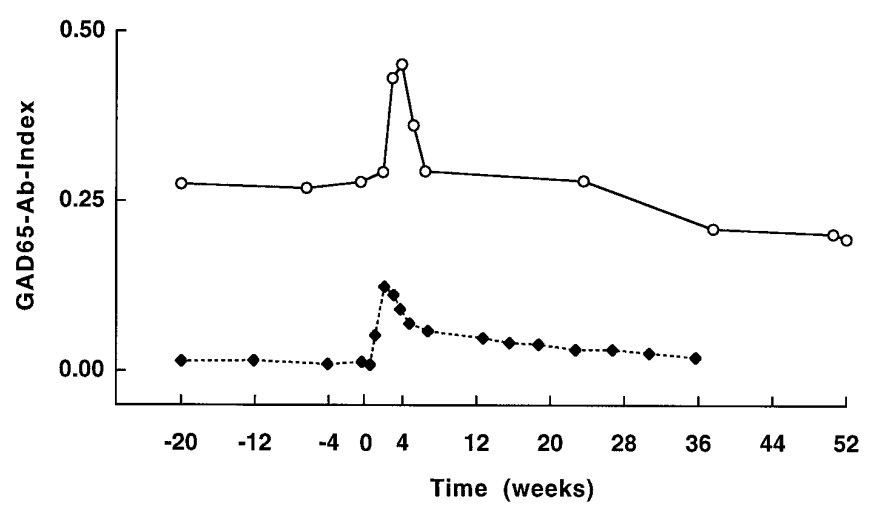

Fig.3. Rise in serum $\mathrm{GAD}_{65}$ antibodies during first weeks post-transplantation in two patients $(\mathrm{E} O, \mathrm{G} \bullet)$ who were $\mathrm{GAD}_{65}$ antibody positive before transplantation. The $\mathrm{GAD}_{65}$ index in non-diabetic individuals is less than 0.009

tomegalovirus (CMV)-positive when using beta-cells from CMV-positive donors in a CMV-negative recipient.

Comparison of recipient and graft characteristics in transplants with different outcome. Transplants with short ( $<3$ weeks) and long $(>52$ weeks) graft survival are compared in terms of recipient and graft characteristics. No obvious differences were noticed in DQ-related relative risk, age at IDDM onset and duration of diabetes, or insulin requirements (Table 1 ). All recipients were ICA-negative, but two of the four with short graft survival were $\mathrm{GAD}_{65}$-antibody positive; after transplantation, ICA and $\mathrm{GAD}_{65}$-antibody negative patients remained negative, but the $\mathrm{GAD}_{65}$-antibody positive patients developed higher titres between post-transplantation weeks 1 and 6 (Fig. 3). At implantation, no differences were noticed in the immunosuppressive treatment of the recipients with short or long-term graft survival (Table 1). However, all three recipients with long-term survival had received anti-thymocyte-globulin as induction immunosuppressive therapy during the first 10 days following their kidney implant, more than 1 year before the beta-cell implantation (Table 1 ). In terms of graft characteristics, no differences were found in donor age, in cold ischaemia time of the pancreatic organs or in cellular composition of the implant (Table 1). Recipients with long-term graft survival did not receive more beta-cells per kg body weight, or an implant with a higher insulin biosynthetic capacity.

Properties of beta-cell allografts leading to insulin-independence. Two grafts with comparable properties induced a state of insulin-independence from posttransplantation month 7 on (patients A and B). They both consisted of minimally $65 \%$ endocrine cells, the majority of which were insulin-positive, and of maximally $35 \%$ duct cells; acinar cells or leukocytes were not detected. A total of, respectively, 1.8 and 1.5 million beta-cells was implanted per $\mathrm{kg}$ body weight with an in vitro insulin biosynthetic capacity of, respectively, 4.4 and $2.0 \mathrm{nmol}$ per graft per hour (Table 1). Thus, at the time of implantation, these grafts would produce 106 and $48 \mathrm{nmol}$ insulin per day if permanently stimulated by glucose. Such insulin production would be 3- and 7-fold lower than the dose injected before implantation (47 and 57 IU/day or 282 and $342 \mathrm{nmol} / \mathrm{day}$ ). Using the quantification 
of other laboratories [23], these grafts provided, respectively, 4400 and 2600 islet equivalents (IEQ) per $\mathrm{kg}$ body weight, which is lower than the amounts transplanted in previous cases of normalization by islet allotransplantation (range of 7900 to 18900 IEQ/ $\mathrm{kg})$ [1-9].

\section{Discussion}

Freshly isolated rodent islets are rapidly rejected following intraportal transplantation in allogeneic recipients, despite immune suppression [10,11]. Culture reduces the immunogenicity of rodent islets [26], probably through depletion in passenger leucocytes [27], reduced MHC-class I expression [28] and/ or preferential loss in non-endocrine cells [29]. This effect helped develop procedures for prolonged survival of beta-cell allografts in rodents without the need for permanent immune suppression [9, 10]. Such perspective makes islet cell transplantation attractive as treatment before appearance of serious complications. So far, the technique has been tested in IDDM patients who had progressed into a late phase of the disease, requiring a kidney allograft and, hence, life-long anti-rejection therapy. When this therapy was combined with anti-lymphocyte globulins at the time of islet transplantaton, $10 \%$ of the recipients, reported to the Islet Transplant Registry exhibited, for at least 1 week, a period of insulin independence beyond the first year post-transplantation, compared to $0 \%$ in patients who did not receive this induction immune therapy [8]. Most implants consisted of non-cultured tissue, injected immediately after isolation, with in some cases a supplement of cryopreserved islets. It is unknown whether culture improves survival of human islet allografts in IDDM patients. The present study uses a recently developed method for serum-free culture of human islets [17], with preservation of functional beta-cells [17] and depletion in damaged cells, leucocytes, MHC-class II positive cells and acinar cells; a final incubation at room temperature reduces MHC-class I expression on the remaining cells [30]. Intraportal transplantation of these beta-cell preparations induced insulinindependence in two cases, who only received a maintenance anti-rejection therapy. In a third case, donor beta-cells also survived longer than 1 year, but C-peptide levels remained in the low range, probably as a result of the $40 \%$ lower beta-cell mass. In the four other cases beta-cells were lost at the same time, i. e. during the third post-transplantation week, which suggests a similar destruction mechanism, the nature of which is still unclear. The three patients who remained C-peptide positive by week 3 did not exhibit any signs of loss in graft function during the subsequent year, indicating that the graft-threatening process might be particularly operative during the first 3 weeks. Pharmacologic suppression during the first weeks post-transplantation might thus be sufficient for a long-term survival of cultured beta-cell allografts in man, as was the case in rodents [11]. In IDDM patients, maintenance doses of cyclosporin, azathioprin and methylprednisolone might be borderline effective in this respect, which could explain why beta-cell function was preserved in only three of seven cases. The association with a history of ATG therapy at the time of their kidney graft might be coincidental, but deserves further attention in trials with this patient category. Parallel analysis of the cellular immune reactivity before and after islet cell implantation (B. Roep et al., study in progress) might indicate differences in the alloreactive status of recipients with a history of ATG treatment.

Comparison of recipient characteristics did not indicate obvious differences in relative risk conferred by the HLA DQ genotype, age at clinical onset of diabetes and duration of the disease, body weight and insulin needs. The one patient with IDDM in first degree relatives ( 3 of 8 ) was in the group without graft survival, as well as the two patients who were $\mathrm{GAD}_{65}$-antibody positive at the time of transplantation. These two patients exhibited a marked rise in antibody titre following transplantation, starting at week 1 when beta-cells were still functional, peaking between week 2 and 4 when beta-cells were destroyed, and returning to baseline levels by week 6 . A recent report also noted rapid islet graft failure in a patient with high $\mathrm{GAD}_{65}$ antibodies [31]. This pattern in $\mathrm{GAD}_{65}$ antibodies is compatible with their role as markers for an immune reactivity against the islet beta-cells $[32,33]$. They may thus become a negative selection criterium for islet cell transplantation and /or an index for inadequate immune suppression of candidate recipients.

The use of cultured islet cells for transplantation has the disadvantage of requiring more donor tissue to prepare a sufficiently large beta-cell mass. On the other hand, this procedure allows inclusion of preparations which would otherwise be discarded in cases of insufficient pancreatic tissue, when segments are procured, or of insufficient yield in the isolation. Furthermore, isolated preparations can now be screened for microorganisms and analysed for their cellular composition and functional properties prior to implantation. Grafts can be composed with comparable characteristics, meeting selected criteria. We chose to implant 1 to 2 million beta-cells per $\mathrm{kg}$ body weight which corresponds to $50 \%$ of the estimated cell number in an adult human pancreas. This dose is 2 to $4-$ fold lower than that previously used for iso- or allografted beta-cells in rats [21, 22]. It was sufficient to correct diabetes in two IDDM patients treated with $50 \mathrm{IU}$ (300 nmol) insulin per day. Insulin-independency was achieved after 7 months, which reflects the insulin injection protocol of an initial intensive insulin 
therapy followed by a slow decrease in daily doses. It was reasoned that reappearence of endogenous insulin secretion would slowly reduce the insulin resistance [34] which is known to exist in insulin-treated patients [35], and as a consequence, reduce daily insulin needs to the amounts that can be produced by grafts with marginally low beta-cell numbers. Before implantation, each graft preparation could produce 50 to $100 \mathrm{nmol}$ insulin per day, 3 to 6 times less than the dose in the daily injections. This in vitro measurement represents only a rough estimate of the in vivo capacity which also depends on the percent engraftment and graft survival, and on the presence of other regulatory factors than those in the test tube. It nevertheless serves - together with the number of intact beta-cells - as a functional parameter for beta-cell grafts which can correct diabetes in IDDM patients. This form of quantification is more accurate than a calculation of the number of dithizone-positive particles: first, dithizone is not specific for beta-cells; second, dithizone-positive particles contain variable percentages of beta-cells; third, the staining does not distinguish living from dead cells; fourth, the method does not assess the functional capacity of the graft. We found no correlation between the number of beta-cells and the number of islet equivalents in the grafts. Furthermore, our two patients who became insulin-independent received markedly lower numbers of islet equivalents than is assumed to be needed for allografts to induce insulin-independence at 1 year or more post-transplantation $[6,8,9]$.

The shortcomings of the dithizone staining make this technique also inaccurate to determine the purity of the human beta-cell preparations. Using electron microscopy and immunocytochemistry, our grafts were found to be 50 to $70 \%$ pure in beta-cells; the glucagon- and somatostatin containing cells represented $15 \%$ and the remaining 15 to $35 \%$ corresponded to pancreatic duct cells. The latter cell type is consistently found in isolated human islet preparations, often attached to the endocrine islet cells. It may therefore go unnoticed in dithizone-stained preparations. Its rapid detection and quantification became possible by cytokeratin staining, as also previously described in other species [36]. It is still unknown whether contaminating duct cells influence the outcome of beta-cell transplantation. The duct cell population might contain beta-cell precursors which could increase the beta-cell mass if adequately stimulated in the implant site. However, human duct cells may also participate in the immune process since they contain MHC-class II positive cells which increase in number following exposure to cytokines [37].

The two patients who became insulin-independent, exhibited adequate control of fasting plasma glucose levels throughout the first post-transplantation year, with normal $\mathrm{HbA}_{1 \mathrm{c}}$ levels. The third patient with low C-peptide levels presented a better metabolic control for lower daily insulin doses. Each of the three patients presented a poor beta-cell secretory response to intravenous glucose. This insensitivity to an acute rise in glucose may result from the fact that all beta-cells are already activated at basal glycaemia, and therefore unresponsive to the cell-recruiting effect of an acute increase in glucose [17]. Their responsiveness to oral glucose probably reflects the amplifying effect of gut peptides which are known to activate synergistic cyclic AMP-dependent signals in pancreatic beta-cells [38, 39]. Stimulation by glucagon supports the view that insulin release from these intraportally transplanted beta-cells is more dependent on variations in neuro(humoral) regulators than on increases in glucose.

Acknowledgements. The authors are indebted to:

the laboratory personnel at the central facility for producing beta-cell grafts at day and night; the surgical teams at the university hospitals in Antwerp (D. Ysebaert), Brussel (G. Willems), Bruxelles (L. De Pauw), Dublin (D. Hickey), Ghent (U. Hesse), Helsinki (J. Ahonen), Leuven (R. Aerts), Louvain (J.P.Squifflet), Malmö (N. Persson), Munich-Ulm (D. Abendroth), Nijmegen (J. A. van der Vliet), Oslo (C. Erichsen), Uppsala-Stockholm (C. Groth) for their collaboration in this program, the Eurotransplant/Bioimplant Services (Leiden, the Netherlands) and their affiliated hospitals for organ procurement, the departments involved in the clinical trial at the Universities of Antwerp (G. Verpooten, K. Van Acker), Ghent (R. Van Holder, R. Rottiers), Leuven (C. Mathieu, M. Waer), Helsinki (V.Koivisto, I. Kellokumpu) and Brussel (G. Somers, S. Lauwers).

The authors also acknowledge the advice and support from the members of the management group of this multicenter program (C. Hellerström, Uppsala; A. Lernmark, Seattle; R. Landgraf, Munich; J. Van Rood, Leiden; B. Cohen, T. de By, ET and BIS Leiden; G. Tomkin, Dublin).

Grant support : The present study was undertaken within the framework of a multicenter program supported by the European Union (Biomed CT92-0805 and CT95-1561), the Vlaamse Gemeenschap (93/019) and the Belgian Ministry of Science (D. P. W. B. CE/03/001), the Juvenile Diabetes Foundation (Diabetes Interdisciplinary Research Grant 95-00) and the Belgian Fonds Wetenschappelijk Onderzoek (3.0057.94). Hospitalization costs were covered by the implantation centers (AZ VUB, Brussels; Surgical Hospital, Helsinki).

\section{References}

1. Scharp DW, Lacy PE, Santiago JV et al. (1991) Results of our first nine intraportal islet allografts in type 1, insulindependent diabetic patients. Transplantation 51: 76-85

2. Warnock GL, Kneteman NM, Ryan EA, Rabinovitch A, Rajotte RV (1992) Long-term follow-up after transplantation of insulin-producing pancreatic islets into patients with type 1 (insulin- dependent) diabetes mellitus. Diabetologia 35: 89-95

3. Ricordi C, Tzakis AG, Carroll PB, Zeng Yet al. (1992) Human islet isolation and allotransplantation in 22 consecutive cases. Transplantation 53: 407-414 
4. Gores PF, Najarian JS, Stephanian E, Lloveras JJ, Kelley SL, Sutherland DE (1993) Insulin independence in type 1 diabetes after transplantation of unpurified islets from single donor with 15-deoxyspergualin. Lancet 341: 19-21

5. Soon-Shiong P, Heintz RE, Merideth N et al. (1994) Insulin independence in a type 1 diabetic patient after encapsulated islet transplantation. Lancet 343: 950-951

6. Hering BJ, Browatzki CC, Schultz A, Bretzel RG, Federlin KF (1993) Clinical islet transplantation - registry report, accomplishments in the past and future needs. Cell Transplantation 2: 269-282

7. Secchi A, Socci C, Maffi P, Taglietti MV et al. (1997) Islet transplantation in IDDM patients. Diabetologia 40: 225-231

8. Hering BJ, Brendel MD, Schultz AO, Schultz B, Bretzel RG (1996) International Islet Transplant Registry Newsletter 56: 1-19

9. Sutherland DER, Gores PF, Hering BJ, Wahoff D, McKeehen DA, Gruessner RW (1996) Islet transplantation: an update. Diab Met Rev 12: 137-150

10. Lacy PE (1993) Status of islet cell transplantation. Diabetes Rev 1: 76-92

11. Pipeleers D, Keymeulen B, Korbutt G (1994) Islet transplantation. In: Marshall S, Home P (eds) Diabetes Annual 8. Elsevier Science Publishers, Amsterdam, pp 299-330

12. Pipeleers D (1994) Treatment of diabetes by islet cell transplantation. In: Baya $\mathrm{C}$ (ed) Biomedical and health research, vol 3. Advances in medical biology. IOS Press, Amsterdam, pp 185-197

13. Gorus FK, Goubert P, Semakula C et al. (1997) IA-2-autoantibodies complement $\mathrm{GAD}_{65}$ - autoantibodies in new-onset IDDM patients and help predict the disease in their siblings. Diabetologia 40: 95-99

14. Vandewalle CL, Decraene T, Schuit FC et al. (1993) Insulin autoantibodies and high titre islet cell antibodies are preferentially associated with the HLA DQA1*0301DQB1*0302 haplotype at clinical onset of type 1 (insulindependent) diabetes before age 10 years but not at onset between age 10-40 years. Diabetologia 36: 1155-1162

15. Leonhardt U, Tytko A, Exner B et al. (1993) The effect of different solutions for organ preservation on immediate postischemic pancreatic function in vitro. Transplantation 55: 11-14

16. Warnock GL, Ellis D, Rajotte RV, Dawidson I, Baekkeskov S, Egebjerg J (1988) Studies of the isolation and viability of human islets of Langerhans. Transplantation 45: 957-963

17. Ling Z, Pipeleers D (1996) Prolonged exposure of human beta cells to elevated glucose levels results in sustained cellular activation leading to a loss of glucose regulation. J Clin Invest 98: 2805-2812

18. Rajotte RV, Warnock GL, Goulombe MG (1988) Islet cryopreservation: methods and experimental results in rodents, large mammals and humans. In: Van Schilfgaarde R, Hardy MA (eds) Transplantation of the endocrine pancreas in diabetes mellitus. Elsevier Science Publishers, Amsterdam, London, New-York, Tokyo, pp 125-135

19. Bouwens L, Lu WG, De Krijger R (1997) Proliferation and differentiation in the human fetal endocrine pancreas. Diabetologia 40: 398-404

20. Lu WG, Pipeleers DG, Klöppel G, Bouwens L (1996) Comparative immunocytochemical study of MHC class II expression in human donor pancreas and isolated islets. Virchows Arch 429: 205-211

21. Keymeulen B, Korbutt G, De Paepe M, Klöppel G, Pipeleers DG (1996) Long-term metabolic control by rat islet grafts depends on the composition of the implant. Diabetes 45: $1814-1821$

22. Pipeleers DG, Pipeleers-Marichal M, Hannaert JC et al. (1991) Transplantation of purified islet cells in diabetic rats. I Standardization of islet cell grafts. Diabetes 40: 908-919

23. Ricordi C, Gray DW, Hering B et al. (1990) Islet isolation assessment in man and large animals. Acta Diabetol Lat 27: $185-195$

24. Stenman UH, Pesonen K, Ylinen K, Huhtala ML, Teramo K (1984) Rapid chromatographic quantitation of glycosylated haemoglobins. J Chromatograph 297: 327-332

25. Bingley PJ, Colman P, Eisenbarth GS et al. (1992) Standardization of IVGTT to predict IDDM. Diabetes Care 15: $1313-1316$

26. Lacy PE, Davie JM, Finke EH (1979) Prolongation of islet allograft survival following in vitro culture $\left(24^{\circ} \mathrm{C}\right)$ and a single injection of ALS. Science 204: 312-313

27. Faustman D, Hauptfeld V, Lacy P, Davie J (1981) Prolongation of murine islet allograft survival by pretreatment of islets with antibody directed to I a determinants. Proc Natl Acad Sci USA 78: 5156-5159

28. Markmann JF, Tomaszewski J, Posselt AM et al. (1990) The effect of islet cell culture in vitro at $24^{\circ} \mathrm{C}$ on graft survival and MHC antigen expression. Transplantation 49: 272-277

29. Pipeleers DG, Pipeleers-Marichal M, Vanbrabandt B, Duys S (1991) Transplantation of purified islet cells in diabetic rats. II Immunogenicity of allografted islet beta cells. Diabetes 40: 920-930

30. Pavlovic D, Van De Winkel M, Van der Auwera B et al. (1997) Effect of interferon- $\gamma$ and glucose on MHC class I and class II expression by pancreatic $\beta$ and non- $\beta$-cells. J Clin Endocrinol Metab 82: 2329-2336

31. Jaeger C, Hering BJ, Dyrberg T, Federlin K, Bretzel RG (1996) Islet cell antibodies and glutamic acid decarboxylase antibodies in patients with insulin-dependent diabetes mellitus undergoing kidney and islet-after-kidney transplantation. Transplantation 62: 424-426

32. Kaufman DL, Clare-Salzer M, Tian J et al. (1993) Spontaneous loss of T-cell tolerance to glutamic acid decarboxylase in murine insulin-dependent diabetes. Nature 366: 69-72

33. Tisch R, Yang XD, Singer SM, Liblau RS, Fugger L, McDevitt HO (1993) Immune response to glutamic acid decarboxylase correlates with insulitis in non-obese diabetic mice. Nature 366: 72-75

34. Luzi L, Hering BJ, Socci C et al. (1996) Metabolic effects of successful intraportal islet transplantation in insulin-dependent diabetes mellitus. J Clin Invest 97: 2611-2618

35. DeFronzo RA, Hendler R, Simonson D (1982) Insulin resistance is a prominent feature of insulin-dependent diabetes. Diabetes 31: 795-801

36. Bouwens L, Wang RN, De Blay E, Pipeleers DG, Klöppel G (1994) Cytokeratins as markers of ductal cell differentiation and islet neogenesis in the neonatal rat pancreas. Diabetes 43: 1279-1283

37. Pavlovic D, Van De Winkel M, Van der Auwera B, Chen MC, Schuit F, Bouwens L, Pipeleers D (1997) Effect of interferon- $\gamma$ and glucose on MHC class I and class II expression by pancreatic $\beta$ and non- $\beta$ cells. J Clin Endocr Metab 82: 2329-2336

38. Creutzfeldt W, Ebert R (1985) New developments in the incretin concept. Diabetologia 28: 565-576

39. Pipeleers D (1987) The biosociology of pancreatic B cells. Diabetologia 30: 277-291 